\title{
KEMISKINAN BERBASIS SUSTAINABLE DEVELOPMENT DI PROVINSI JAWA TIMUR
}

\author{
Yunita Firdha Kyswantoro \\ Fakultas Ekonomi dan Bisnis Universitas Brawijaya \\ Email: yunitafirdhak@gmail.com
}

\begin{abstract}
Poverty is one of the goals of the concept of sustainable development. Sustainable Development itself has many indicators such as economic, social, cultural, environment, etc. But in this study, the authors take only a few factors from an economic point of view. Economic growth, open unemployment rate, regional imbalance rate and human development index are some factors that are considered to describe poverty level in East Java Province. This research uses Fixed Effect (FEM) model panel data regression in 38 regencies/cities in East Java Province in 2011-2015. The results of this study indicate that the variables of economic growth and open unemployment variables have no significant effect in describing the level of poverty in East Java. While the variable level of regional imbalance and variable of HDI have the significant effect on poverty in East Java. Therefore, to achieve sustainable development goals (SDGs), the reduction of poverty in various regions requires a balance of social and economic, not only through the increase of high economic growth but must be accompanied with equitable distribution of income distribution so that the level of regional inequality is smaller and by improving the quality of resources human beings through Human Development Index (HDI) in each region.
\end{abstract}

Keywords : Sustainable Development, kemiskinan, pertumbuhan ekonomi, TPT, ketimpangan wilayah, IPM

\section{PENDAHULUAN}

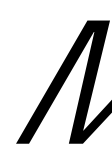

enurut Arsyad (2002) pembangunan ekonomi suatu wilayah dapat memberikan kemampuan pada masyarakatnya untuk mengatur segala potensi sumberdaya yang dimiliki. Namun dengan potensi sumberdaya serta cara pengembangan yang berbeda pada tiap wilayah memicu timbulnya suatu "gap". Sehingga menimbulkan kemiskinan antar wilayah. Kemiskinan ini dapat menjadi kendala dalam rangka pembangunan regional berbasis sustainable development. Banyak para peneliti yang tertarik untuk membahas masalah kemiskinan kedalam Research Paper mereka karena banyak faktor yang bisa ditarik untuk 
dijadikan berbagai alasan atas terjadinya masalah tersebut. Berdasarkan data Garis Kemiskinan Menurut Provinsi di Pulau Jawa tahun 2013-2015, Provinsi Jawa Timur berada pada peringkat keempat dari 6 Provinsi lainnya. Walaupun jika dilihat secara keseluruhan tingkat kemiskinan yang ada pada Provinsi Jawa Timur sudah cukup kecil, namun angka dari garis kemiskinan tersebut dari tahun 2013-2015 terus meningkat.

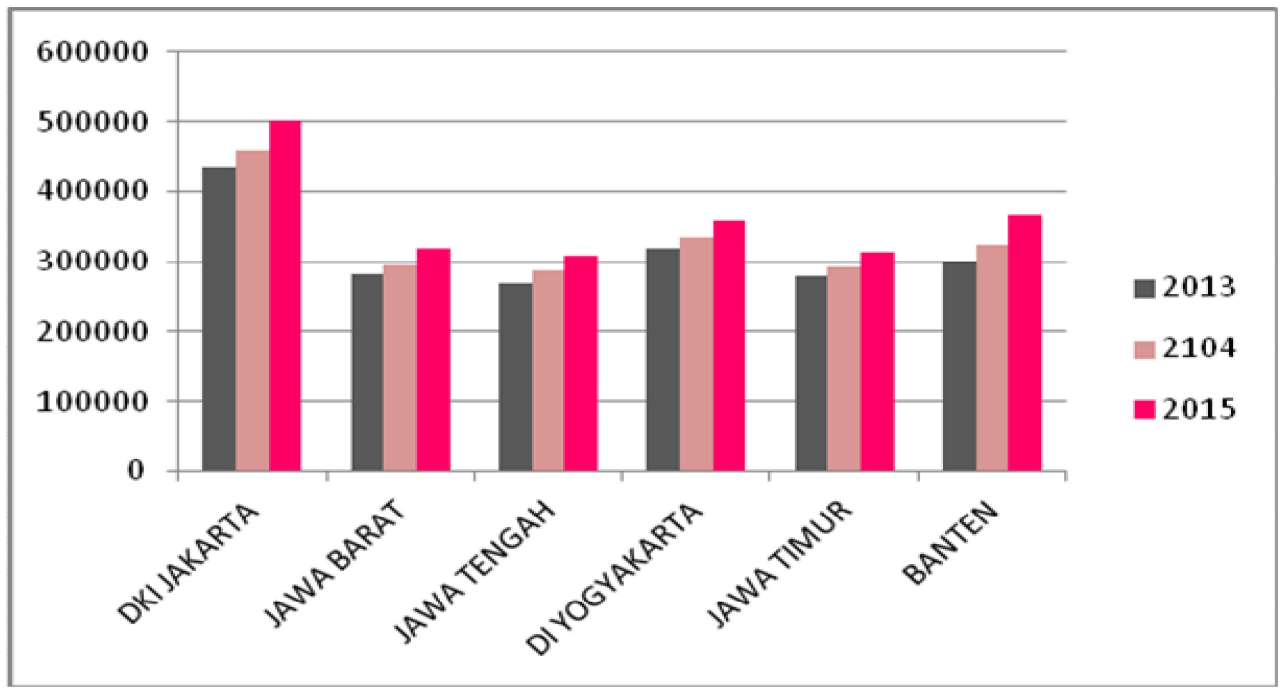

Sumber : BPS 2016

Gambar 1. Garis Kemiskinan Perkotaan Menurut Provinsi (Rupiah)

Dalam rangka pembangunan ekonomi regional yang bersifat sustainable yaitu suatu konsep pembangunan ekonomi yang bertujuan untuk menciptakan keseimbangan antara ekonomi, sosial, dan pembangunan pada suatu wilayah (World Commission on Environment and Development (Brutland, 1987)). Dengan tingkat kemiskinan yang semakin meningkat maka terjadi hambatan untuk mencapai keadaan sustainable tersebut. Sustainable Development sendiri memiliki banyak indikator, contohnya ekonomi, sosial, lingkungan dll. Namun dalam penelitian kali ini, penulis hanya mengambil beberapa faktor dari sudut pandang ekonomi.

Pertumbuhan ekonomi adalah salah satu indikator untuk mengetahui tingkat kemiskinan yang terjadi antar wilayah di Provinsi Jawa Timur. Terlihat pada data bahwa pertumbuhan ekonomi secara keseluruhan mengalami penurunan yang cukup signifikan pada tahun 2013 yaitu dari $6.08 \%$ ke $5.44 \%$ pada tahun 2015 . Hal ini juga berdampak pada tingkat 
kemiskinan Provinsi Jawa Timur yang juga meningkat. Padahal untuk mencapai keseimbangan pembangunan ekonomi yang bersifat sustainable diperlukan peningkatan pertumbuhan ekonomi sehingga dapat mengurangi angka kemiskinan pada suatu wilayah.

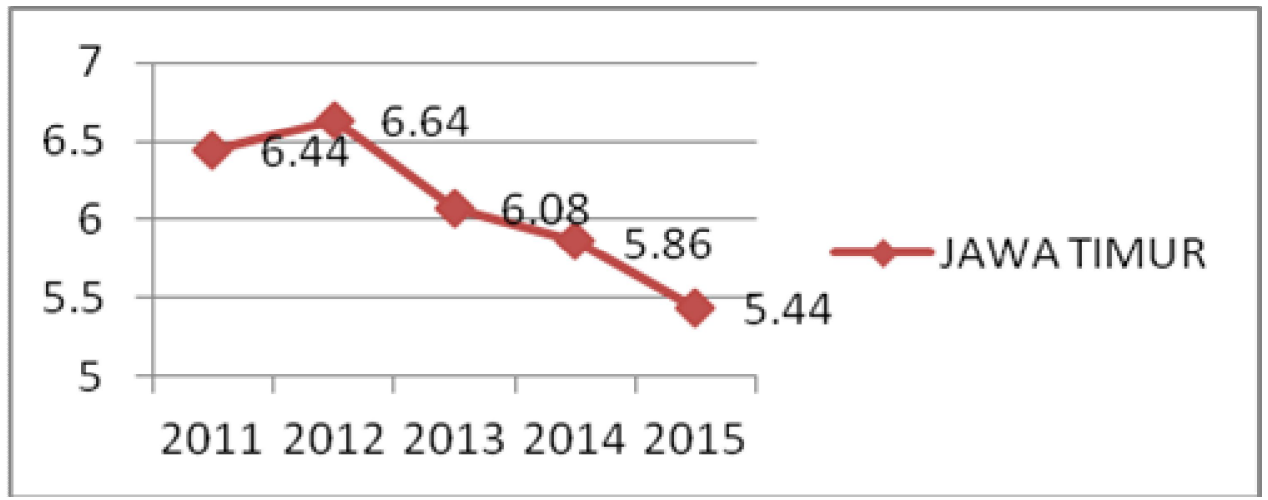

Sumber : BPS 2016

Gambar 2. Pertumbuhan Ekonomi Provinsi Jawa Timur 2011-2015 (\%)

Penelitian dari Jonadi (2012) mengenai analisis pertumbuhan ekonomi dan kemiskinan di Indonesia, variabel pertumbuhan ekonomi berpengaruh signifikan dan berhubungan negatif terhadap kemiskinan Indonesia dengan nilai koefisien 0,9585. Yang berarti jika pertumbuhan ekonomi meningkat maka kemiskinan akan turun. Hasil penelitian ini sama dengan penelitian yang dilakukan (Suryahadi, Suryadarma, \& Sumarto, 2006) dari SMERU.

Mankiw (2007) menyatakan dengan meningkatnya pertumbuhan ekonomi akan meningkatkan produksi sehingga dapat menyerap tenaga kerja bagi masyarakat miskin dengan demikian pembangunan ekonomi regional yang bersifat sustainable akan tercapai. Penelitian dari Endriana (2011) yaitu mengenai analisis faktor penyebab kemiskinan di Nanggroe Aceh Darussalam, variabel tingkat pengangguran terbuka (TPT) berpengaruh signifikan terhadap kemiskinan di Provinsi NAD dan berhubungan negatif. Yaitu jika TPT naik maka terjadi penurunan terhadap tingkat kemiskinan sebesar $0,094724 \%$. Namun hal ini tidak sesuai dengan teori yang menyatakan bahwa jika tingkat pengangguran meningkat maka tingkat kemiskinan juga meningkat. 


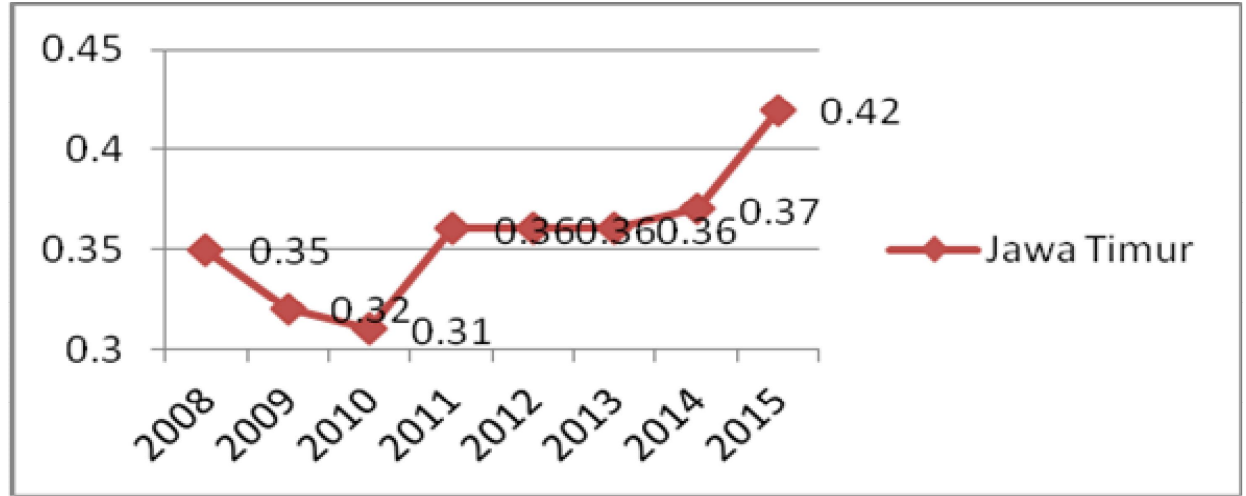

Sumber : BPS 2016

Gambar 3. Gini Ratio Provinsi Jawa Timur 2008-2015

Tingkat ketimpangan antar wilayah sangat penting pada pembangunan ekonomi yang bersifat sustainable dikarenakan dengan rendahnya tingkat ketimpangan wilayah akan mengurangi tingkat kemiskinan. Berdasarkan grafik diatas yaitu tingkat disparitas wilayah melalui Indeks Gini tahun 2015 sebesar 0,42 \% yang berarti kondisi Jawa Timur berada pada tingkat disparitas sedang (Badan Pusat Statistik, 2016). Jika ketimpangan antara wilayah maju dan berkembang tinggi maka akan semakin tinggi pula wilayah yang berpenduduk miskin (Arsyad, 2010)

Selain itu IPM (Indeks Pembangunan Manusia) juga merupakan indikator yang perlu diteliti dalam hal penyebab kemiskinan. IPM dianggap dapat menggambarkan perkembangan kualitas manusia dalam rangka pencapaian sustainable development. Salah satu indikator IPM adalah tingkat pendidikan, berdasarkan penelitian variabel tingkat pendidikan berhubungan negatif dan signifikan sebesar -1,327 terhadap kemiskinan (Utomo, 2010). Serta penelitian yang dilakukan oleh Endriana (2011), variabel IPM menunjukkan hasil yang signifikan terhadap kemiskinan serta berhubungan negatif. Yaitu jika IPM naik maka kemiskinan akan menurun sebesar 4,15799\%. Dan hasil penelitian ini sesuai jika dihubungkan dengan teori.

Berdasarkan latar belakang permasalahan tersebut diatas, maka penulis merasa perlu diadakan penelitian mengenai permasalahan "Analisis faktor yang mempengaruhi kemiskinan berbasis sustainable development di Provinsi Jawa Timur Tahun 2011 - 2015" dengan tujuan menganalisis pengaruh pertumbuhan ekonomi, Tingkat pengangguran terbuka (TPT), 
Tingkat ketimpangan (Indeks Gini), serta Indeks Pembangunan Manusia (IPM) terhadap tingkat kemiskinan dalam rangka pembangunan ekonomi regional yang berbasis sustainable di Provinsi Jawa Timur tahun 2011 - 2015

\section{METODE PENELITIAN}

Penelitian ini akan mengamati pengaruh pertumbuhan ekonomi, Tingkat pengangguran terbuka (TPT), Tingkat ketimpangan (Indeks Gini), serta Indeks Pembangunan Manusia (IPM) terhadap tingkat kemiskinan pada 38 Kabupaten/kota Provinsi Jawa Timur. Maka untuk menjawab permasalahan serta tujuan tersebut peneliti memilih menggunakan metode kuantitatif dengan periode pengamatan tahun 2011 - 2015. Metode analisis yang digunakan yaitu analisis regresi data panel dengan dua metode Fixed Effect Method (FEM) dan Random Effect Method (REM) (Gujarati, 2002). Namun sebelum dilakukan pengestimasian model dalam penelitian ini, dilakukan uji spesifikasi untuk menganalisis antara penggunaan FEM atau REM yaitu menggunakan Uji Hausman (Hausman-test). Berikut model ekonometrika dari penelitian ini :

$$
K=\beta_{0}+\beta_{1} P E+\beta_{2} T P T+\beta_{3} I G+\beta_{4} I P M+\varepsilon
$$

Keterangan :

Kemiskinan $=$ Tingkat Kemiskinan

$\mathrm{PE}=$ Pertumbuhan Ekonomi

TPT $=$ Tingkat Pengangguran Terbuka

IG = Tingkat Ketimpangan (Indeks Gini)

IPM = Indeks Pembangunan Manusia

$\beta_{0} \quad=$ Konstanta

$\beta_{1,2,3,4,3}=$ Koefisien Regresi (variabel yang diestimasi)

$\varepsilon=$ Error term (variabel gangguan)

\section{HASIL DAN PEMBAHASAN}

Gambaran Umum Kemiskinan di Provinsi Jawa Timur

Permasalahan kemiskinan merupakan permasalahan krusial yang dihadapi oleh berbagai wilayah serta dapat menghambat proses pembangunan ekonomi regional. Pada dasarnya PBB telah menentapkan 17 tujuan dengan 169 capaian dari sustainable development dan tujuan pertama yaitu Pemberantasan kemiskinan dengan salah satu capaiannya adalah 
mengakhiri kemiskinan dalam segala bentuknya diseluruh wilayah. Maka penelitian ini menjadi penting karena dapat mengetahui faktor-faktor yang mempengaruhi kemiskinan sehingga dapat mencapai dari sustainable development goals (SGDs) yang ada pada Provinsi Jawa Timur.

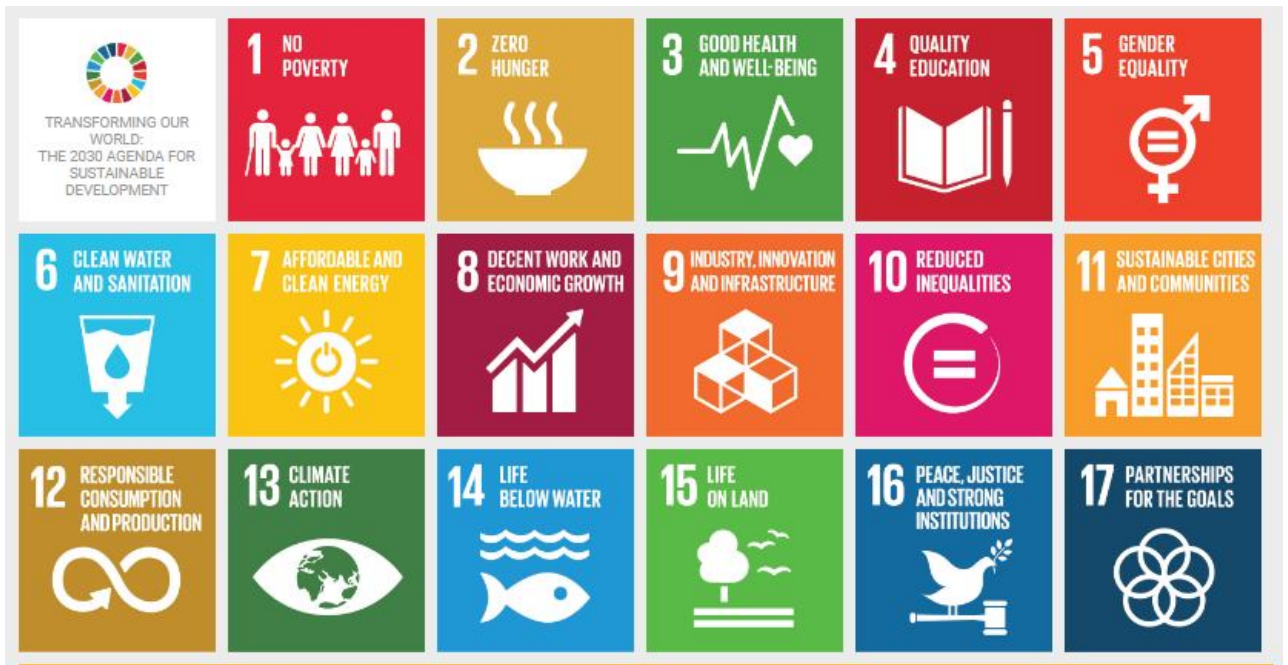

Sumber : SDGs, 2016

Gambar 4. Sustainable development Goals (SDGs)

PDRB Provinsi Jawa Timur adalah tertinggi kedua di Indonesia namun juga memiliki jumlah penduduk miskin yang tinggi pula jika dibandingkan dengan tingkat kemiskinan nasional. Berdasarkan data terlihat bahwa dari tahun 2005-2014 tingkat kemiskinan Jawa Timur selalu lebih tinggi dibandingkan tingkat kemiskinan nasional. Hal ini berarti jumlah penduduk miskin yang ada di Jawa Timur lebih banyak dibanding dengan rata-rata jumlah penduduk miskin di Provinsi lain. Dari tahun 2005 ke 2006 tingkat kemiskinan jawa timur dan nasional mengalami kenaikan, kenaikan ini dipengaruhi oleh salah satunya kenaikan harga BBM menjadi hampir 87.50\%. Namun pada tahun 2007-2014 prosentase tingkat kemiskinan terus menurun.

Hasil uji regresi data panel ini menggunakan Fixed Effect Model (FEM). Dengan variabel dependen yaitu Kemiskinan (Y), dan variabel independennya yaitu Pertumbuhan Ekonomi (X1), Tingkat pengangguran terbuka (X2), Ketimpangan regional/wilayah (X3), dan Indeks pembangunan manusia (X4). Berikut model regresi berdasarkan hasil analisis data diatas : 
$Y=13,56864-0,002481 X 1+0,002468 X 2+0,379677 X 3-2,666597 X 4+E$

Tabel 1. Hasil Uji Regresi Data

Dependent Variable: $Y$

Method: Panel Least Squares

Date: 12/18/16 Time: 12:11

Sample: 20112015

Periods included: 5

Cross-sections included: 38

Total panel (balanced) observations: 190

\begin{tabular}{lllll}
\hline \hline Variable & Coefficient & Std. Error & t-Statistic & Prob. \\
\hline \hline X1 & -0.002481 & 0.003111 & -0.797399 & 0.4265 \\
X2 & 0.002468 & 0.004099 & 0.602069 & 0.5480 \\
X3 & 0.379677 & 0.160948 & 2.359000 & 0.0196 \\
X4 & -2.666597 & 0.267604 & -9.964711 & 0.0000 \\
C & 13.56864 & 1.134062 & 11.96463 & 0.0000 \\
\hline \hline
\end{tabular}

Effects Specification

Cross-section fixed (dummy variables)

\begin{tabular}{llll}
\hline \hline R-squared & 0.987761 & Mean dependent var & 2.452353 \\
Adjusted R-squared & 0.984371 & S.D. dependent var & 0.436108 \\
S.E. of regression & 0.054521 & Akaike info criterion & -2.788185 \\
Sum squared resid & 0.439928 & Schwarz criterion & -2.070422 \\
Log likelihood & 306.8776 & Hannan-Quinn criter. & -2.497430 \\
F-statistic & 291.3382 & Durbin-Watson stat & 1.916461 \\
Prob(F-statistic) & 0.000000 & & \\
\hline \hline
\end{tabular}

$C A R=$ Capital Adequacy Ratio

GCREDIT $=$ Pertumbuhan Kredit Perbankan

GER = Pertumbuhan Nilai Tukar Rupiah terhadap US Dollar

GIHSG $=$ Pertumbuhan Indeks Harga Saham Gabungan

$J I B O R=3$ Month JIBOR rate

$L D R=$ Loan to Deposit Ratio

LEND = Tingkat suku bunga rata-rata kredit perbankan

GMS $=$ Pertumbuhan Jumlah Uang Beredar

$N P L=$ Non Performing Loan

ROA $=$ Return on Asset 
Koefisien regresi variabel pertumbuhan ekonomi (X1) yang bernilai 0,002481 menjelaskan bahwa apabila terjadi peningkatan pada variabel pertumbuhan ekonomi sebesar 1 satuan maka akan terjadi penurunan pada variabel kemiskinan (Y) sebesar 0,002481. Selanjutnya pada koefisien regresi variabel tingkat pengangguran terbuka (X2) yang bernilai 0.002468 menjelaskan bahwa jika terjadi kenaikan variabel tingkat pengangguran terbuka sebesar 1 satuan maka akan meningkatkan pula variabel kemiskinan (Y) sebesar 0.002468. Pada variabel ketiga yaitu variabel ketimpangan regional (X3) atau yang di jelaskan melalui data indeks gini, koefisien regresinya bernilai 0,379677. Menjelaskan bahwa terjadinya peningkatan variabel ketimpangan regional sebesar 1 satuan maka akan meningkatkan variabel kemiskinan (Y) sebesar 0,379677. Dan variabel terakhir yaitu IPM (X4) koefisien regresinya -2.666597 yang berarti kenaikan 1 satuan IPM akan menurunkan variabel kemiskinan $(\mathrm{Y})$ sebesar 2.666597 .

Berdasarkan output hasil regresi dapat diketahui Koefisien determinasi $\left(\mathrm{R}^{2}\right)$ sebesar 0,987761 atau sebesar $98,7 \%$. Ini berarti bahwa kontribusi dari variabel $\mathrm{X} 1, \mathrm{X} 2, \mathrm{X} 3$ dan $\mathrm{X} 4$ dapat menjelaskan pengaruhnya terhadap variabel kemiskinan $(\mathrm{Y})$ sebesar $98,7 \%$. Sedangkan sisanya yaitu sebesar $1,3 \%$ dijelaskan oleh variabel lain diluar persamaan regresi pada penelitian kali ini.

Uji F statistik digunakan untuk menguji hipotesis pengaruh simultan dari variabel X terhadap variabel Y. Berdasarkan hasil didapatkan Sig F $(0,000)$ yang lebih kecil dari $5 \%(0,05)$ menunjukkan bahwa $\mathrm{H} 1$ diterima dan $\mathrm{H} 0$ ditolak yang berarti bahwa variabel $\mathrm{X} 1, \mathrm{X} 2, \mathrm{X} 3$ dan $\mathrm{X} 4$ secara bersama sama mempunyai pengaruh yang signifikan terhadap variabel kemiskinan $(Y)$.

Selanjutnya dilakukan uji t statistik untuk mengetahui pengaruh parsial dari masing-masing variabel $X$ terhadap variabel $Y$. Berikut hasil dari uji parsial masing-masing variabel independen terhadap variabel dependen :

- Variabel pertumbuhan ekonomi (X1) dengan nilai signifikansi 0,4265 (lebih besar dari alpha $5 \%$ atau 0,05 ) yang berarti bahwa variabel pertumbuhan ekonomi (X1) tidak berpengaruh signifikan terhadap variabel Kemiskinan $(\mathrm{Y})$.

- Variabel tingkat pengangguran terbuka (X2) dengan nilai signifikansi 0,5480 (lebih besar dari alpha $5 \%$ atau 0,05 ) yang berarti bahwa 
variabel tingkat pengangguran terbuka (X2) tidak berpengaruh signifikan terhadap variabel Kemiskinan (Y).

- Variabel ketimpangan regional (X3) dengan nilai signifikansi 0,0196 (lebih kecil dari alpha 5\% atau 0,05) yang berarti bahwa variabel ketimpangan regional (X3) berpengaruh signifikan terhadap variabel Kemiskinan (Y).

- Variabel IPM (X4) dengan nilai signifikansi 0,000 (lebih kecil dari alpha $5 \%$ atau 0,05 ) yang berarti bahwa variabel IPM (X4) berpengaruh signifikan terhadap variabel Kemiskinan (Y).

Pembahasan Hasil Analisis

Dalam penelitian kali ini terdapat variabel dependen yaitu Kemiskinan $(Y)$ dengan variabel independen berbasis pada sustainable development sudut pandang ekonomi yaitu variabel pertumbuhan ekonomi (X1), tingkat pengangguran terbuka (X2), ketimpangan regional (X3), dan IPM (X4).

Tabel 2. Pengaruh dan hubungan antar variabel

\begin{tabular}{cccc}
\hline & Variabel & Hasil Output & Keterangan \\
\hline Variabel & KEMISKINAN $(\mathrm{Y})$ & & \\
Dependen & \multicolumn{1}{c}{$(\mathrm{X} 1)$} & & \\
\hline Variabel & $\begin{array}{c}\text { Pertumbuhan Ekonomi } \\
\text { Independen }\end{array}$ & Negatif & Tidak Signifikan \\
\cline { 2 - 4 } & $\begin{array}{c}\text { Tingkat Pengangguran } \\
\text { Terbuka }(\mathrm{X} 2)\end{array}$ & Positif & Tidak Signifikan \\
\cline { 2 - 4 } & $\begin{array}{c}\text { Tingkat Ketimpangan } \\
\text { regional (X3) }\end{array}$ & Positif & Signifikan \\
& $\begin{array}{c}\text { Indeks Pembangunan } \\
\text { Manusia }(\mathrm{X} 4)\end{array}$ & Negatif & Signifikan \\
& & & \\
\hline
\end{tabular}

Sumber : penulis, 2016

Setelah dilakukan regresi data panel melalui model fixed effect diperoleh hasil bahwa variabel X1 yaitu Pertumbuhan ekonomi berhubungan negatif dengan kemiskinan dan tidak begitu berpengaruh terhadap kemiskinan. Dengan kata lain bahwa pertumbuhan ekonomi tinggi yang terjadi di Provinsi Jawa Timur belum tentu efektif dalam mengakhiri kemiskinan antar wilayah. Pertumbuhan ekonomi antar wilayah Provinsi Jawa Timur masih belum merata. 


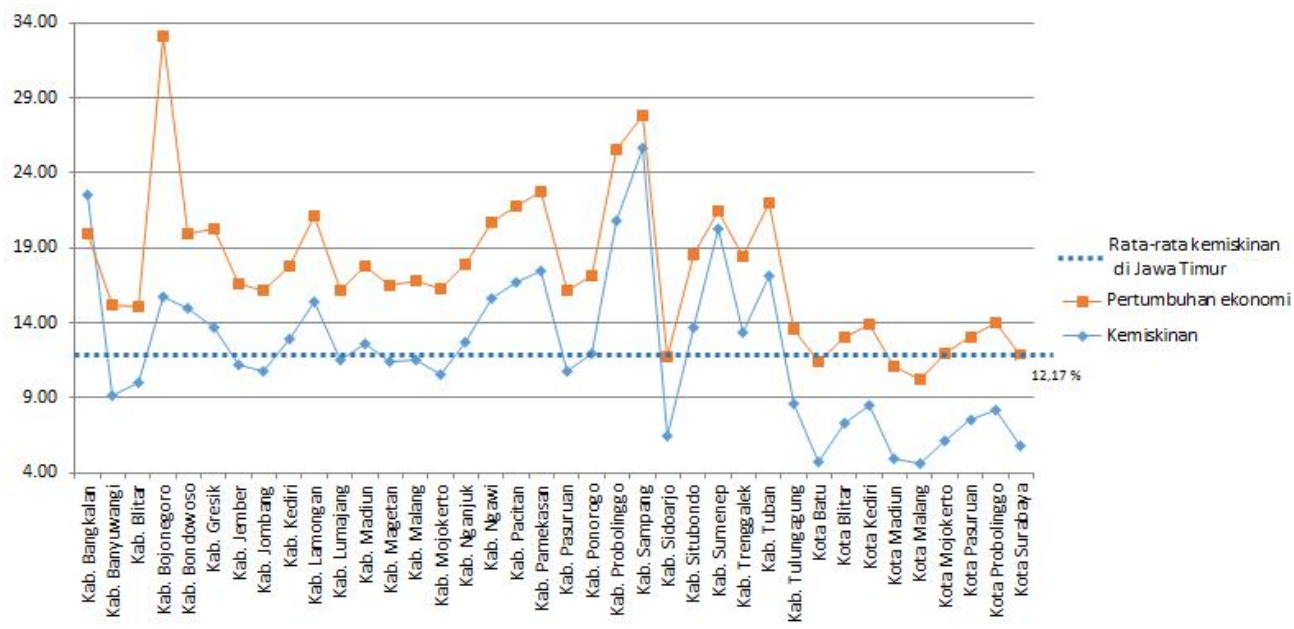

Sumber : BPS, 2016

Grafik 5. Tingkat kemiskinan dan Pertumbuhan Ekonomi Kab/Kota Provinsi Jawa Timur tahun 2016

Seperti halnya pada wilayah Kabupaten Bojonegoro pada tahun 2015 kontribusi pertumbuhan ekonominya tertinggi $(17,42 \%)$ jauh lebih besar jika dibandingkan dengan pertumbuhan ekonomi nasional (5,86\%). Namun kemiskinan yang terjadi pada Kabupaten Bojonegoro juga sangatlah tinggi $(15,71 \%)$ sedangkan rata-rata kemiskinan nasional yaitu pada garis putusputus berwarna biru hanya sekitar $12,17 \%$. Sehingga bisa dikatakan bahwa tingginya pertumbuhan ekonomi suatu wilayah tidak berpengaruh terhadap kemiskinan. Pertumbuhan ekonomi belum bisa menggambarkan pengaruhnya dalam rangka mencapai pembangunan ekonomi regional yang sustainable.

Selain itu pertumbuhan ekonomi bisa dikatakan masih dinikmati oleh sebagian pemilik modal dan belum merata kepada seluruh lapisan masyarakat. Dengan begitu akan menyebabkan tingginya masyarakat yang masuk kedalam kategori penduduk miskin. Jika dibandingkan dengan konsep Trickle Down Effect yaitu pertumbuhan ekonomi akan mempersempit gap antara si miskin dengan si kaya maka pada penelitian kali ini tidak sesuai. 


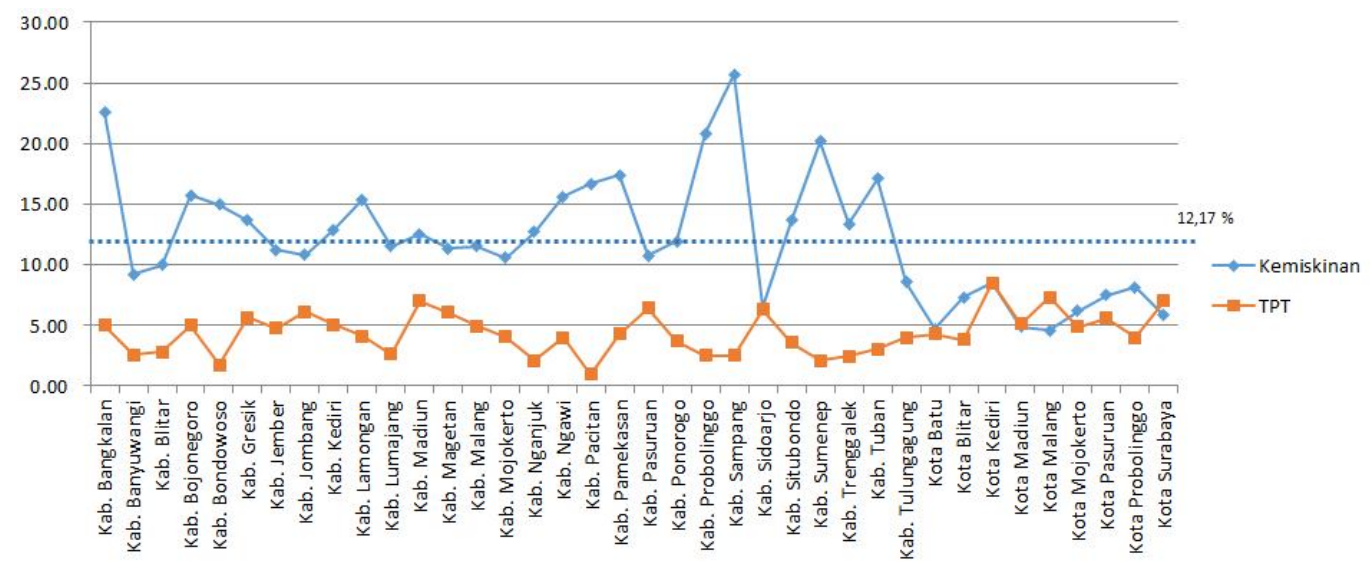

Sumber : BPS, 2016

Grafik 6. Tingkat kemiskinan dan Tingkat Pengangguran Terbuka Kab/Kota Provinsi Jawa Timur tahun 2016

Variabel selanjutnya yaitu Tingkat pengangguran terbuka mempunyai hubungan yang positif namun tidak mempunyai pengaruh yang signifikan dalam program pengentasan kemiskinan wilayah. Pada pembahasan sebelumnya menyatakan bahwa sustainable development tidak hanya dapat diukur melalui peningkatan pertumbuhan ekonomi namun mempunyai keterkaitan yang erat dengan masalah rendahnya lapangan kerja yang ada di wilayah tersebut. Pada dasarnya jika tingkat pengangguran terbuka masih tinggi maka banyak masyarakat yang menganggur sehingga semakin banyak masyarakat yang masuk dalam katergori miskin. TPT tertinggi yaitu berada pada kota Kediri tahun 2015 (8,46\%) padahal jika dilihat melalui kemiskinannya masih dibawah rata-rata nasional $(12,17 \%)$ sehingga bisa dikatakan bahwa TPT belum dapat menggambarkan pengaruhnya terhadap tingkat kemiskinan dalam rangka mencapai pembangunan ekonomi regional yang sustainable.

Dalam rangka pembangunan ekonomi regional yang bersifat sustainable seharusnya pemerintah dapat memprogram kebijakan yang mengarah pada labour intensive sehingga akan meningkatkan lapangan kerja yang dapat banyak menyerap tenaga kerja bagi masyarakat miskin dengan demikian pembangunan ekonomi regional yang bersifat sustainable akan tercapai. 

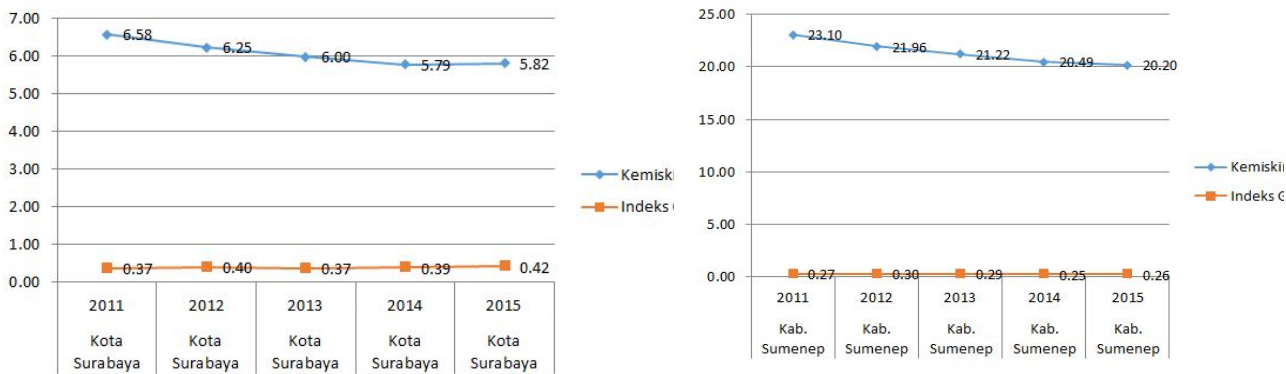

Sumber : BPS, 2016

Grafik 7. Tingkat Kemiskinan dan Tingkat Ketimpangan pada Kota Surabaya (Tertinggi IG) dan Kab. Sumenep (Terendah IG) Tahun 2011 - 2015

Tingkat ketimpangan wilayah yang diukur melalui indeks gini memberikan hasil yang signifikan dan berhubungan positif terhadap kemiskinan di Provinsi Jawa Timur. Hal ini berarti jika terjadi peningkatan tingkat ketimpangan regional maka akan meningkatkan pula tingkat kemiskinan. Sebagai contohnya pada kota Surabaya (tingkat ketimpangan tertinggi se Jawa Timur) tingkat ketimpangannya meningkat dari tahun 2014 ke 2015 menyebabkan kemiskinan juga meningkat. Tingkat ketimpangan wilayah di Surabaya tertinggi dikarenakan sebagai pusat perekonomian di Jawa Timur, Surabaya mempunyai tingkat kepadatan yang sangat tinggi dan pdrb tertinggi pula namun perekonomian pada wilayah tersebut masih dikuasai oleh golongan tertentu sehingga semakin memperbesar gap si kaya dan si miskin.

Dengan tingginya ketimpangan wilayah maka akan menurunkan tingkat kesejahteraan masyarakat pada masing-masing wilayah. Sustainable development tidak dapat berjalan jika hanya satu komponen ekonomi yang berjalan, sustainable development disini diharapkan terjadinya titik keseimbangan antara sosial, ekonomi, budaya (Leidig, Teeuw, \& Gibson, 2016). Maka percuma jika suatu wilayah pertumbuhan ekonominya tinggi namun tingkat ketimpangan wilayah tersebut juga sangat tinggi hal ini jelas akan meningkatkan tingkat kemiskinan dan pembangunan ekonomi seperti ini bukanlah berbasis oleh sustainable development yang sekarang sedang berlangsung. Sesuai dengan teori pertumbuhan seimbang Rodan \& Nurkse bahwa dengan pengembangan industrialisasi di daerah kurang berkembang adalah cara untuk memperbaiki ketimpangan yang ada sehingga kemiskinan bisa menurun (Arsyad, 2010). 
Begitupula dengan IPM, berdasarkan hasil penelitian kali ini Indeks Pembangunan Manusia (IPM) berhubungan negatif dan berpengaruh signifikan. Maka jika terjadi peningkatan IPM di Provinsi Jawa Timur maka akan menurunkan tingkat kemiskinan. Pada Kota Sidoarjo memiliki IPM tertinggi pada tahun $2015(0,80 \%)$ tingkat kemiskinan yang terjadi juga lebih rendah $(6,16 \%)$ jika dibandingkan dengan rata-rata kemiskinan nasional (12,17\%). Pada uji parsial, koefisien regresi dari IPM merupakan yang paling tinggi yaitu -2.666597 terhadap kemiskinan. Hal ini menunjukkan bahwa variabel IPM mempunyai pengaruh yang paling tinggi diantara variabel lain.

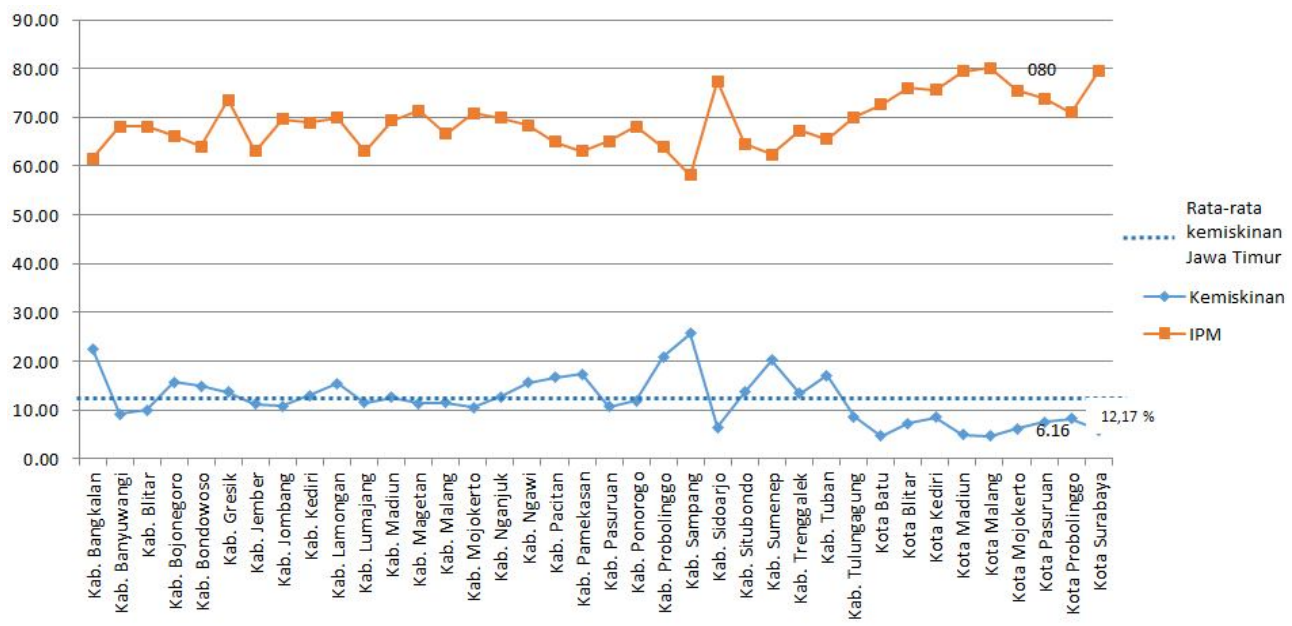

Sumber : BPS, 2016

Grafik 8 Tingkat kemiskinan dan IPM Kab/Kota Provinsi Jawa Timur tahun 2016

Pembangunan ekonomi yang bersifat sustainable jelas sangat pro terhadap peningkatan kualitas sumberdaya manusia. IPM sendiri pada dasarnya dapat menggambarkan sekaligus tiga komponen yaitu umur panjang dan sehat, pengetahuan (pendidikan), serta standar hidup layak. Jika pemerintah fokus dalam hal peningkatan kualitas SDM melalui IPM maka diharapkan akan mengurangi tingkat kemiskinan yang ada melalui peningkatan angkatan kerja, peningkatkan pembangunan ekonomi maupun penurunan tingkat ketimpangan wilayah. Konsep Sustainable development dengan konsep IPM yaitu sejalan, jika kualitas SDM meningkat maka prospek pada generasi masa depan juga akan lebih baik, akan terjadi pembenahan pada model pembanguan ekonomi regional QE Journal | Vol.06 - N 0.02 July 2017 - 131 
sehingga bisa bersifat sustainable. Hal ini juga sesuai dengan Irawan \& Suparmoko (2011) bahwa sustainable development memprioritaskan peningkatan kapsitas generasi yang akan datang dengan cara peningkatan SDM dan modal.

\section{SIMPULAN DAN SARAN}

Penelitian ini bertujuan untuk menganalisis pengaruh pertumbuhan ekonomi, Tingkat pengangguran terbuka (TPT), Tingkat ketimpangan (Indeks Gini), serta Indeks Pembangunan Manusia (IPM) terhadap tingkat kemiskinan dalam rangka pembangunan ekonomi regional yang bersifat sustainable di Provinsi Jawa Timur tahun 2011 - 2015. Maka berdasarkan hasil analisis menggunakan regresi data panel melalui model Fixed Effect sebagai berikut :

- Hasil analisis menunjukkan bahwa pertumbuhan ekonomi, tingkat pengangguran terbuka, ketimpangan regional, dan IPM secara bersama-sama berpengaruh signifikan terhadap tingkat kemiskinan di Provinsi Jawa Timur.

- Namun melalui uji parsial menunjukkan bahwa variabel pertumbuhan ekonomi (X1) dan variabel tingkat pengangguran terbuka (X2) tidak berpengaruh signifikan terhadap Kemiskinan. Sedangkan tingkat ketimpangan (X3) dan IPM (X4) berpengaruh signifikan terhadap kemiskinan. Pada dasarnya pembangunan ekonomi regional yang berbasis sustainable diharapkan mampu mengentas kemiskinan sehingga terjadi kesejahteraan yang lebih baik dimasa yang akan datang.

- Berdasarkan penelitian kali ini cara yang efektif untuk mencapai dari sustainable development goals (SDGs) yaitu pengentasan kemiskinan di berbagai daerah tidak hanya melalui peningkatan pertumbuhan ekonomi yang tinggi namun harus disertai dengan keseimbangan pemerataan distribusi pendapatan sehingga tingkat ketimpangan wilayah semakin kecil serta dengan cara peningkatan kualitas sumberdaya manusia melalui Indeks Pembangunan Manusia (IPM) di masing-masing wilayah. 


\section{DAFTAR PUSTAKA}

Arsyad, L. (2002). Pengantar Perencanaan Dan Pembangunan Ekonomi Daerah. Yogyakarta: BPFE.

Arsyad, L. (2010). Ekonomi Permbanguan (5th ed.). Yogyakarta: UPP. STIM YKPN.

BadanPusatStatistik. (2016). No Title. Retrieved from http://www.bps.go.id/

Brutland. (1987). World Commission on Environment and Development.

Endriana, E. (2011). ANALISIS TINGKAT KEMISKINAN SEBAGAI DAMPAK DARI BENCANA TSUNAMI DI PROVINSI NANGGROE ACEH DARUSSALAM. digilib feb ub. Universitas Brawijaya.

Gujarati, D. N. (2002). Dasar - Dasar Ekonometrika (5th ed.). Jakarta: Salemba Empat.

Irawan, \& Suparmoko, M. (2011). Ekonomika Pembangunan (5th ed.). Yogyakarta: BPFE.

Jonadi, A. (2012). Analisis Pertumbuhan Ekonomi Dan Kemiskinan Di Indonesia. Jurnal Kajian Ekonomi, 1(April), 140-164.

Leidig, M., Teeuw, R. M., \& Gibson, A. D. (2016). Data poverty: A global evaluation for 2009 to 2013 - implications for sustainable development and disaster risk reduction. International Journal of Applied Earth Observation and Geoinformation, 50, 1-9. https://doi.org/10.1016/j.jag.2016.03.001

Mankiw, N. G. (2007). Makroekonomi (6th ed.). Jakarta: Erlangga.

SDGs. (2016). No Title. Retrieved from https://sustainabledevelopment.un.org/sdgs

Suryahadi, A., Suryadarma, D., \& Sumarto, S. (2006). Economic Growth and Poverty Reduction in Indonesia: The Effects of Location and Sectoral Components of Growth. SMERU Research Institute.

Utomo, A. E. S. S. dan agung priyo. (2010). Faktor-Faktor Yang Mempengaruhi Kemiskinan Secara Makro Di Lima Belas Provinsi Tahun 2007. Jurnal Organisasi Dan Manajemen, 6(2), 89-100 